\title{
7. ANALYSIS ON URBAN ECOSYSTEM CHANGES AROUND SUBWAY NETWORK
}

\author{
地下鉄網周辺地区の都市生態変化の分析 \\ Etsuo YAMAMURA*, Jothimani PONNUSAMY** \\ 山村 说夫 ジョティマニ ポンヌサミ
}

\begin{abstract}
Metropolitan growth trends throughout rapid suburban sprawl as well as urban renewal/dynamics ecosystem changes needs to be inter-linked to the urban land use and ecosystem changes based on transportation networks. The resultant impact of urban ecosystem changes on the population concentration results in the increasing pressure on the infrastructure facilities also poses high vulnerability risks. In order to meet all the needs of the entire urban ecosystem changes, a approach using a geographical information systems (GIS) is presented with the capabilities of data input, updating and manipulation for multi purpose research and be called urban ecosystem changes around subway network.
\end{abstract}

KEYWORD; Ecosystem changes, Subway network, Geographical information systems

\section{Introduction}

Keeping in view of the emerging trends in disaster mitigation efforts and planning strategies, the primary objective is to correlate the changing pattern of urban land uses and its potential natural hazards and demonstrate the utility of GIS in urban disaster mitigation planning. The efficient algorithms available within GIS were utilized for various spatial and overlay operations performed with the multi data sets which includes subway network, land use, population, soil texture and elevation data. This includes the digital mosaicing from 5 topographical maps on 1:25,000 for generation of theme layers of subway network land use $(1977,1993)$, population $(1975,1990)$, soils/subsurface stratum elevation data from topographical maps. The land use classes with less than $0.03 \mathrm{~mm}$ was merged with the nearby classes, due to complex nature of analysis involved and constraints of time.

\section{Growth profile of Sapporo city}

"Sapporo" an ainu word, means "large dry land" or "important river flowing through a marsh". In 1880, a railroad was established between Sapporo and Otaru, a major port city $34 \mathrm{~km}$ to the west. Twenty years later industrial development including coal mining helped in reshaping Hokkaido. In 1892 the population of Sapporo was 127,044 within an area of 24 sq. km. Hokkaido became into limelight after world war II , since it remained intact. The Hokkaido Comprehensive Development Plan of 1950 encouraged industrial expansion which brought influx of population from the mainland Honshu and continued to be one of the most preferred cities. The winter Olympics of 1972 gave a facelift to the city and its environment, including the establishment of subway network

\footnotetext{
${ }^{*}$ Graduate School of Environmental Earth Science, Hokkaido University 北海道大学大学院 地球環境科学研究科

${ }^{* *}$ Hitachi Zosen Information Systems Co.,Ltd. 日立造船情報システム株式会社
} 
of which the recent phase of Susukino-Fukuzumi line was opened in 1994. Recent studies on Sapporo city's evolution and growth (Jitsu, 1989) and its changing land uses (Jitsu 1977, 1981, 1995) reveal greater significance of conversions of lowlands in the Northern plains as well as in the eastern suburban areas (Teraya and Iwasaki, 1991) encircling terminals of the subways (Jothimani and Yamamura, 1996a, 1996b, 1996c) and also resulted in larger scale changes in natural ecosystems.

Sapporo is located in the southwestern part of Ishikari plain and consists of mountainous areas (more than 60\%) and plains of river basins of Ishikari and Toyohira. The river Toyohira, the tributary of Ishikari, which originates in the western part of the city traverses through the urban core and relatively plain area where it joins with its main river Ishikari. The topography of this regional setting consists of relatively of lowlands with alluvial soil deposits. Thus the entire urban activity of main urban core and the suburbs are concentrated within the "Sapporo fan" formed the Toyohira river.

Sapporo is one of the Major Metropolitan Areas (MMA's) other than Tokyo, Osaka, Nagoya and Yokohama. Glickmann (1976) observed that Yokohama and Sapporo had registered more than 100 percent population change other than the conurbation's of Tokyo, Osaka and Nagoya within the Regional Economic Clusters (REC's) as early as in 1950-70 period. It is widely believed that post 1970 era has witnessed huge investment for industrialization and its regional development and growth of Hokkaido, a prefecture (a regional administrative unit) in northern Japan. Sapporo city $\left(140^{\circ} 59^{\prime}-141^{\circ} 30^{\prime} \mathrm{E}\right.$ and $\left.42^{\circ} 46^{\prime}-43^{\circ} 11^{\prime} \mathrm{N}\right)$ being the capital of Hokkaido Prefecture, has witnessed quicker phase of urbanization. It has $30 \%$ share of its total population of 5,677,437 and also the fifth largest in Japan and has a population of 1,693,371 (Government of Japan-Population Census, 1990). Even though the urbanization has continued its phase, the geographical area of the city is limited to $1118.01 \mathrm{~km}^{2}$, except in 1990 when Atsubetsu and Teine wards were suffixed to the city area. It extends $42.30 \mathrm{~km}$ in east-west and $45.40 \mathrm{~km}$ in north-south direction with $363 \mathrm{~km}$ circumferential distance and the highest elevation at Mt. Muine $(1461 \mathrm{~m})$.

Sapporo was the fourth city of Japan to have its subway network other than Tokyo, Osaka, and Nagoya which was gradually developed in various phases from early eighties during the preparations for Winter Olympics of 1972 and continued thereafter until 1994 (Government of Japan-Hokkaido Government, 1995). The first phase (Kita 24 chome - Makomanai) of subway of North-South line (NAN-POKU) in direction was completed by 1971 and was extended later upto Asabu in the north (total $14 \mathrm{~km}$ ). Then various phases of East-West line (TOZAI) from Kotoni to Shiroishi $(9.7 \mathrm{~km})$ was completed by June 1976 with the extension from Shiroishi to ShinSapporo $(7.4 \mathrm{~km})$ completed (total $17.1 \mathrm{~km}$ ) by May 1982. The North-SouthEast line (TOHO) from Sakae-machi to Susukino was completed by September 1988 and Susukino to Fukuzumi was completed (total $16 \mathrm{~km}$ ) by December 1994. Present case study is focused along the buffer zone of 500 meters of the network.

Topographical maps of Geographical Survey institute on 1:25,000 were used for digitization of subway network. The newly constructed portion of subway line from Susukino- Fukuzumi were complied from other sources such as Handbooks of Sapporo city office as well as the continuation of road networks and other alignments within topographical map. The elevation points were extracted for the buffer-grid zones of the subway and entered in the form of grid-points.

The detailed and available third-order urban land use maps (1977 and 1993) on 1:25,000 scale prepared by the Geographical Survey Institute, which is responsible for preparation and dissemination of topographical/thematic maps in Japan (Akagiri, 1986). Even though these land use maps are the secondary source of information, these has the advantages of being updated from the satellite data (LANDSAT TM), aerial and conventional ground surveys wherever applicable (Masaharu and Kamiya, 1987). In addition, these are the only synoptic, comprehensive, consistent and authoritative source for the detailed third-order urban land uses as well as other spatial extent of natural ecosystem units with consistent classification categories. Unique advantages of 
compatibility of direct input in a GIS system with less complications like data reformatting, reclassification etc. also prompted to use this data as a basis for this analysis. The theme layers derived from these are used as Land use 1977 and 1993.

The grid squares based on the Standard Grid Square System of the country are delineated by dividing the entire geographic area, into rectangles of about $1 \mathrm{sq} . \mathrm{km}$. The tabulation of grid- square statistics of population are derived from the census supervisors, through the grid-square boundaries and the central point of population from the Enumerated Districts (ED) maps of the 1990 population census. The central point is determined by the municipal supervisors on the basis of the population distribution within the ED. The points are recorded by adhering to the rules as prescribed by the Census. Based on these grid-square-basis from each ED data of the population. The statistical maps on Grid Square Basis are shown by the rank of the result (Government of Japan - Population Census, 1990). The grid squares based on the Japanese Standard Grid Square System of the country which are delineated by dividing the entire geographic area, into rectangles of about $1 \mathrm{sq}$. km. It has three hierarchical level i.e.., First order covering $80 \times 80 \mathrm{~km}$ area equivalent to one topographical map series on $1: 200,000$, second order covering $10 \times 10 \mathrm{~km}$ equivalent to one topographical map series on $1: 25,000$ and third order covering $1 \times 1 \mathrm{~km}$ equivalent $10 \times 10$ matrix of the second order in general. The tabulation of grid-square statistics of population are derived from the census supervisors through the grid-square boundaries and the central point of population from the Enumerated Districts (ED) maps of the 1990 population census. The central point is determined by the municipal supervisors on the basis of the population distribution within the ED. The points are recorded by adhering to the rules as prescribed by the Census. The statistical maps on Grid Square Basis are shown by the rank of the result (Government of Japan - Population Census, 1990). The 1975 and 1990 population data of the third-order (1 $\mathrm{km} \times$ $1 \mathrm{~km}$ ) grid was extracted from this data and entered for the study area of the subway network.

\section{Ecosystems conversions to urban uses}

The results of this analysis are derived from the generation of summary statistics from the two land use (1977 and 1993) coverages clipped and overlaid within the buffer zone of 500 meters of the subway network. The detailed break-up shows mainly the pattern of conversions of natural ecosystem units into diverse urban land uses. The land use summary statistics for 1977 and 1993 with detailed break-up of areas with no change, loss and gains. It is observed that these are occurred mainly around the terminals of the subway network, i.e.., Asabu, Sakae-machi and ShinSapporo.

The detailed analysis show that there is predominant increase in the areas of high/medium residential as well as commercial areas. Decline in the areas under the categories of Industrial, Public uses and Educational uses were observed. There growth under the category of parks and sports use and emergence of a welfare center use which was not observed in 1977. It is equally interested to note that there is only marginal increase in the areas under the Transportation and warehouses categories, whereas increase of areas for roads and railway lines are comparatively quite phenomenal. This also may be due to the fact that multi-uses of these are not possible and thus has to be grown considerably in pace with the urbanization trends. It also appears that there is lot of activity is seen in the modification of river front including both river and river-bank, since the area under rivers decreased, whereas area under channeled river has increased. While there is small reduction in the area under the category of the forests, there seems to be near complete loss of agroecosystem areas like vegetable farms, orchards as well as wetlands like marshes. It appears that increased pressure on the open spaces has also led to the reduction of almost $60 \%$ of the open spaces.

The conversions mainly occurred within the main urban core activity classes like commercial, high-rise residential, industrial, educational and public uses. It is observed that there is considerable amount of conversions of public and educational uses which has been converted into commercial or 
residential high/medium categories. There seems to be remarkable loss of residential low, medium/ high and commercial categories to the areas under parks, educational, recreational areas/sports, Transportation and warehouses category and vice-versa among all of these categories. It shows the existence of higher correlation ship for competition among the urban use classes and the process of loss and gain from and within urban core categories as mentioned above.

The observations reveal that almost entire Agricultural fallow/Marsh areas were converted into many urban land uses. There can be well noticed near the eastern terminal node of TOZAI subway line (Kotoni-ShinSapporo) i.e.., Shin-Sapporo and the northern terminal nodes of Asabu (NANPOKU line) and Sakae-machi (TOZAI line). Major ecosystem changes are $100 \%$ conversion of vegetable farms (whereas $25 \%$ gain from other uses), loss of almost $90 \%$ of marshes, more than $85 \%$ of orchards and more than $60 \%$ of open spaces. Almost $90 \%$ of the parks are converted mostly into residential medium/high or commercial uses whereas around $50 \%$ were gained from other uses. One of the salient observation is the conversion of marshy canal into an expressway. This can be observed (a broad linear loop running north-south) near Shin-Sapporo and also an east-west linear loop just south of the Asabu - Sakaemachi area.

\section{References}

Akagiri, T. (1986) On the fundamentals conceptions and purpose of land use map series, Geographical Survey Institute, Bulletin, 30: 25-43.

Glickman, N. J. (1976) On the Japanese Urban system, Journal of Regional Science, 16: 317-336.

Government of Japan - Population Census (1990) Statistical maps on Grid square basis - Results from the 1990 Population Census Results, Management and Coordination Agency.

Government of Japan - Hokkaido Government (1995) Handbook of Sapporo today, Sapporo city Office.

Jitsu, K. (1977) Research on the growth and change of land use in Sapporo city, Memoirs of Faculty of Education, Toyama University, Japan, 25: 35-44 (in Japanese).

Jitsu, K. (1981) Towards a theory of land use system- Case study in Kihanshin metropolitan area, Sapporo and Toyama city, Memoirs of Faculty of Education, Toyama university, Japan, 25:4753 (in Japanese).

Jitsu, K. (1989) The urban growth of Sapporo-viewed from the perspectives of land use and land price, pp 223-232, In (eds.). R.D.Hill, Land-use change, Proceedings of the IGU study group on the dynamics of land use Systems, Hongkong University Press, Hongkong.

Jitsu, K. (1995) Evaluation of land, Memoris of Nara University (Japan) No.23, (in Japanese with abstract in English).

Jothimani, P. \& Yamamura, E. (1996a) Geographical Information Systems and Satellite Remote Sensing techniques for monitoring land use dynamics in Metropolitan cities: An integrated approach for Indian cities, pp 429-438 In (eds.) R.B.Singh, Disasters, Environment and Development, Oxford \& India Book House Publishers, New Delhi.

Jothimani, P. \& Yamamura, E. (1996b) Impact of Urbanization on Ecosystems: A case study of Sapporo city, Japan Using GIS (ARC/INFO), Proceeding of the 5th World Congress of Regional Science Association International (RSAI), Tokyo, vol 3, pp CS-1-3-3.1 to 3.7.

Jothimani, P. \& Yamamura, E. (1996c) Spatial changes in urban land use and ecosystems units arising due to Subway network in Sapporo city using Geographical Information Systems, Studies in Regional Science, 25:1, pp 247-255.

Masaharu, H. \& Kamiya, I. (1987) Land use survey using LANDSAT satellite data, Geographical Survey Institute Bulletin 31:36-50.

Teraya, R. \& Iwasaki, K. (1991) Urban landuse in Sapporo city (1935-1987) Proc. of International Symposium on Environmental change and GIS, Aug 25-28, 1991, Asahikawa, Japan, pp 251259. 